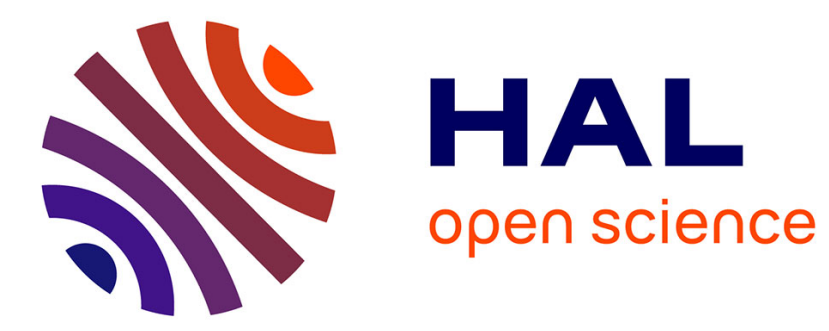

\title{
Parasite co-infection of two sympatric bivalves, the Manila clam (Ruditapes philippinarum) and the cockle (Cerastoderma edule) along a latitudinal gradient
}

Géraldine Lassalle, Xavier de Montaudouin, Philippe Soudant, Christine Paillard

\section{To cite this version:}

Géraldine Lassalle, Xavier de Montaudouin, Philippe Soudant, Christine Paillard. Parasite coinfection of two sympatric bivalves, the Manila clam (Ruditapes philippinarum) and the cockle (Cerastoderma edule) along a latitudinal gradient. Aquatic Living Resources, 2007, 20, pp.33-42. 10.1051/alr:2007013 . hal-00645736

\section{HAL Id: hal-00645736 \\ https://hal.univ-brest.fr/hal-00645736}

Submitted on 28 Nov 2011

HAL is a multi-disciplinary open access archive for the deposit and dissemination of scientific research documents, whether they are published or not. The documents may come from teaching and research institutions in France or abroad, or from public or private research centers.
L'archive ouverte pluridisciplinaire HAL, est destinée au dépôt et à la diffusion de documents scientifiques de niveau recherche, publiés ou non, émanant des établissements d'enseignement et de recherche français ou étrangers, des laboratoires publics ou privés. 


\title{
Parasite co-infection of two sympatric bivalves, the Manila clam (Ruditapes philippinarum) and the cockle (Cerastoderma edule) along a latitudinal gradient
}

\author{
Géraldine Lassalle $^{1}$, Xavier de Montaudouin ${ }^{1, a}$, Philippe Soudant ${ }^{2}$ and Christine Paillard ${ }^{2}$ \\ 1 Université Bordeaux 1 - CNRS - UMR EPOC 5805 - Station marine d'Arcachon, 2 rue du Professeur Jolyet, 33120 Arcachon, France \\ 2 Institut Universitaire Européen de la Mer, Laboratoire des sciences de l'environnement marin - LEMAR, UMR 6539 Université de Bretagne \\ Occidentale-CNRS, Technopôle Brest-Iroise, Place Nicolas Copernic, 29280 Plouzané, France
}

Received 27 September 2006; Accepted 13 March 2007

\begin{abstract}
Among the potential biotic factors affecting population dynamics, parasitism has received relatively little attention. The purpose of this study was to inventory marine bivalve parasites and to investigate relations between different parasite communities. Five intertidal stations along the French Atlantic shore were studied between Brittany and Arcachon Bay. Two bivalves (the edible cockle, Cerastoderma edule, and the Manila clam, Ruditapes philippinarum) were sampled and examined. The parasites included a bacterium (Vibrio tapetis), a protozoan (Perkinsus sp.), and digenetic trematode metacercariae (10 species). Perkinsus sp. prevalence and density in clams were higher than those measured in cockles (30250 vs. 36 cells g $^{-1}$ of gill wet weight, respectively) while digeneans were more common in cockles (46 metacercariae per cockle host vs. 1 per clam host). Distributions of digeneans and Perkinsus sp. were similar along the Atlantic shore. However, at each sampling station and at the individual scale, no correlation between Perkinsus sp. and digenean abundance was detected. These results suggest different ecological niches used by these two parasites within a community of bivalves but a similar response to environmental factors such as temperature and salinity. Vibrio tapetis was found at relatively high prevalence in all stations for both bivalve species (from 17\% to 43\% in cockles and from $23 \%$ to $50 \%$ in clams), but was associated with a low prevalence of Brown Ring Disease (BRD), a shell disease caused by this pathogen. No statistically significant relationship of these parasitic bacteria with trematodes and Perkinsus sp. was evidenced in the present study.
\end{abstract}

Key words: Bivalve mollusc / Digenea /Parasites / Host specificity / Infectivity / NE Atlantic Ocean

Résumé - Co-infestation de parasites chez deux mollusques bivalves, la palourde (Ruditapes philippinarum) et la coque (Cerastoderma edule) le long d'un gradient latitudinal. Parmi les facteurs biotiques pouvant affecter la dynamique de populations, le parasitisme a reçu relativement peu d'attention. Le but de cette étude est d'inventorier les parasites de bivalves marins et de rechercher les relations entre les différentes communautés de parasites. Cinq stations intertidales le long du littoral français, entre la Bretagne et la baie d'Arcachon, ont été étudiées. Deux espèces de bivalves, la coque (Cerastoderma edule) et la palourde (Ruditapes philippinarum) ont été échantillonnées et examinées. Les parasites présents sont une bactérie (Vibrio tapetis), un protozoaire (Perkinsus sp.) et des métacercaires de trématodes digènes (10 espèces). La prévalence et la densité de Perkinsus sp. dans les palourdes sont supérieures à celles mesurées pour les coques ( 30250 vs. 36 cellules $\mathrm{g}^{-1}$ de branchies, respectivement) alors que les trématodes digènes sont plus communs dans les coques (46 métacercaires par coque vs. 1 pour les palourdes). La répartition géographique de Perkinsus sp. et celle des trématodes digènes sont similaires le long du littoral atlantique. Cependant, lorsque l'on considère séparément chaque station d'échantillonnage, aucune corrélation entre Perkinsus sp. et les trématodes digènes en terme d'abondance n'a été détectée à l'échelle individuelle. Ces résultats suggèrent l'utilisation de niches écologiques différentes par Perkinsus sp. et les trématodes digènes mais une même réponse aux caractéristiques environnementales comme la température et la salinité. Des prévalences relativement importantes de Vibrio tapetis ont été trouvées à chaque station et pour les deux espèces de bivalves (de $17 \%$ à $43 \%$ dans les coques et de $23 \%$ à $50 \%$ dans les palourdes), néanmoins, elles sont associées à de faibles prévalences des symptômes de la maladie de l'anneau brun (MAB), une maladie de la coquille causée par ce pathogène. Aucune relation statistiquement significative n'a pu être établie entre la présence de cette bactérie et celle des deux autres parasites (trématodes, Perkinsus sp.).

\footnotetext{
${ }^{a}$ Corresponding author:

x.de-montaudouin@epoc.u-bordeaux1.fr
} 


\section{Introduction}

Population dynamics of marine invertebrates are controlled by a variety of abiotic and biotic factors. Among these, some have received less attention from marine ecologists because of their "discrete nature". This is the case for parasitism. Commercial marine bivalves such as the edible cockle (Cerastoderma edule) and the Manila clam (Ruditapes philippinarum) host a number of common marine parasites which are responsible for mass mortalities and economic losses in Europe (Desclaux 2003; Paillard 2004; Villalba et al. 2004)

In Manila clams, two major pathogens have been described along the Atlantic coast of France: Vibrio tapetis, a marine bacterium and etiological agent of the Brown Ring Disease (BRD), which induces a characteristic symptom: a brown ring deposit of melanised shell matrix on the inner surface of the valves (Paillard and Maes 1995a,b). The other, Perkinsus sp., is a protozoan that causes Perkinsosis, a disease creating lesions in different tissues including the feeding and respiratory system (Villalba et al. 2004).

The cockle, Cerastoderma edule, is known to host many different parasite species and in particular digenean trematodes. Most of these species use cockles as the second intermediate host and the metacercariae generally encyst in specific tissues (foot, mantle, digestive gland) (Lauckner 1983; de Montaudouin et al. 2000). Reported effects induced by the presence of metacercariae in bivalves include reduced ability to burrow (Jensen et al. 1999), reduced byssal thread production (Lauckner 1983), low tolerance to anoxia (Wegeberg et al. 1999) and impaired growth (Calvo-Ugarteburu and McQuaid 1998a,b).

Most investigations of host-parasite systems take into account a single host and a single parasite. Relatively few studies have reported on co-occurrence of different parasite groups, especially between macro- and microparasites (Ngo and Choi 2004). The aims of our study were (i) to inventory the parasite species along a latitudinal gradient within the French Atlantic coast for two host species (cockle and Manila clam), (ii) to determine the host specificity for each agent and (iii) to explore relationship between different types of infection at population and individual scales.

\section{Material and methods}

\subsection{Sampling sites}

In January 2005, a sampling of natural beds was performed along the French Atlantic coast, between Landéda (northern Brittany) and Arcachon (southern Bay of Biscay) to obtain a pattern of co-infection for both host species (Fig. 1). The five sampling sites were semi-sheltered intertidal sandflats favourable for development of bivalve communities. Landéda's sediments are dominated by fine sand (median grain size: $180 \mu \mathrm{m}$ ). Salinity remains high year-round (34-35 psu) due to the oceanic position of this site. Mean surface water temperature fluctuates between $9{ }^{\circ} \mathrm{C}$ in winter and $19^{\circ} \mathrm{C}$ in summer. Ile aux Oiseaux, in the eastern part of Gulf of Morbihan, is characterized by fresh water input by the Auray River, high salinity fluctuations (29-35 psu), and high seasonal

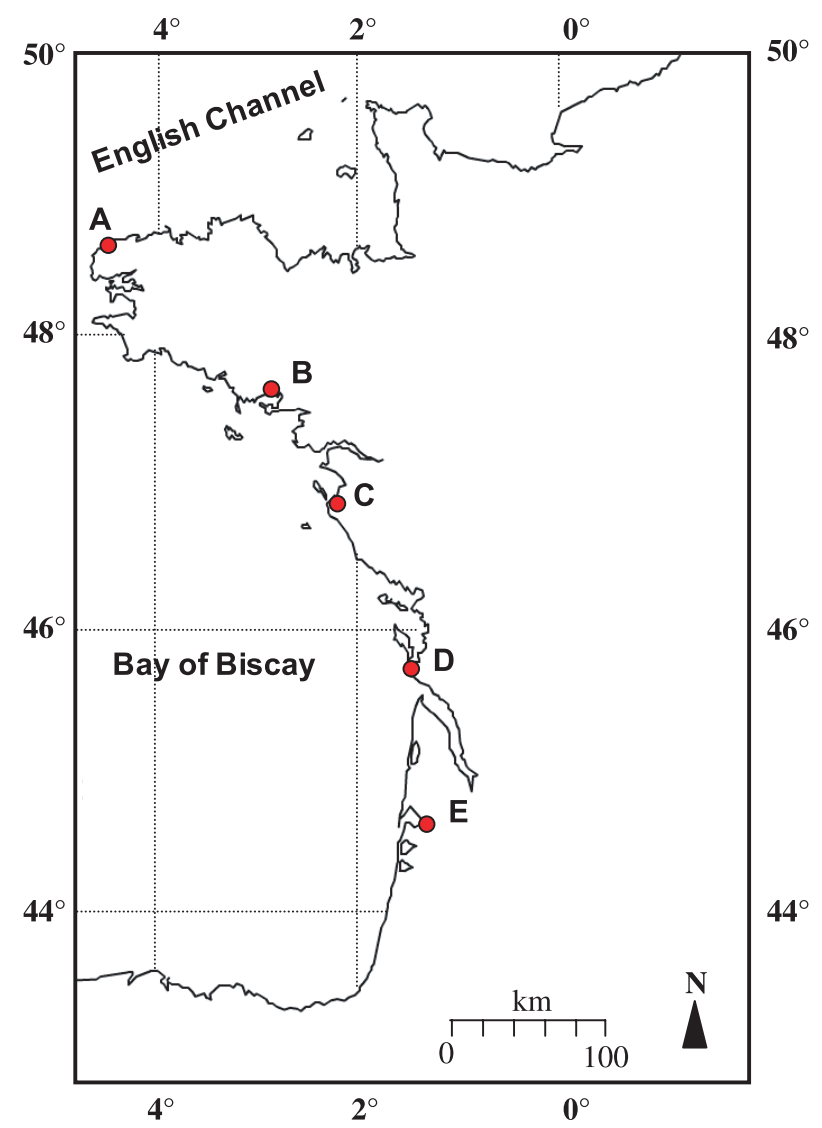

Fig. 1. Cockles and clams sampling in five sites along the French Atlantic coast (A: Landéda $\left(48^{\circ} 36^{\prime} \mathrm{N}, 4^{\circ} 35^{\prime} \mathrm{W}\right)$; B: Golfe du Morbihan/Ile aux Oiseaux $\left(47^{\circ} 35^{\prime} \mathrm{N}, 2^{\circ} 47^{\prime} \mathrm{W}\right) ; \mathbf{C}$ : Baie de Bourgneuf/Ile de Noirmoutier $\left(46^{\circ} 53^{\prime} \mathrm{N}, 2^{\circ} 08^{\prime} \mathrm{W}\right)$; D: Pertuis Charentais/lle d'Oléron $\left(45^{\circ} 51^{\prime} \mathrm{N}, 1^{\circ} 11^{\prime} \mathrm{W}\right) ; \mathbf{E}$ : Bassin d'Arcachon/Chenal d'Andernos $\left(44^{\circ} 42^{\prime} \mathrm{N}, 1^{\circ} 06^{\prime} \mathrm{W}\right)$

variations of water temperatures $\left(3{ }^{\circ} \mathrm{C}\right.$ in winter and $23{ }^{\circ} \mathrm{C}$ in summer). Sediments of the island flats are dominated by medium sand (median grain size: $300 \mu \mathrm{m}$ ). Ile de Noirmoutier, at the mouth of the Bay of Bourgneuf, is also characterized by medium sand (median grain size: $375 \mu \mathrm{m}$ ), relatively high salinity ( 31 to $36 \mathrm{psu}$ ), and temperatures from 3 to $22{ }^{\circ} \mathrm{C}$. Ile d'Oléron is characterized by muddy sands with high organic content (median grain size: $80 \mu \mathrm{m}$ ). Salinity fluctuates between 30 to 34 psu and surface water temperature between 6.5 to $21{ }^{\circ} \mathrm{C}$. The southern most site, in Arcachon Bay, near the Andernos channel, is a Zostera noltii seagrass bed that receives fresh water input from the Leyre River. The median grain size is $142 \mu \mathrm{m}$ (fine sand), the salinity ranges from 22 to $32 \mathrm{psu}$ and the temperature from 1 to $25^{\circ} \mathrm{C}$.

\subsection{Sampling and sample treatment}

At each site, 30 cockles and 30 clams were randomly sampled. Shell length was measured to the nearest $\mathrm{mm}$ with a calliper. For each individual, after elimination of the pallial fluid, the extrapallial fluid was collected with a needle inserted under the mantle, taking care not to damage the tissue, as described 
by Paillard et al. (2006). Extrapallial fluids were frozen immediately at $-20{ }^{\circ} \mathrm{C}$ to be analyzed later for Vibrio tapetis presence. Shells were given the same number as the soft tissue samples so that a record of all parasites and disease signs was kept for each individual. Shells were kept for macroscopic examination (Brown Ring Disease detection). Instruments for dissection were disinfected with alcohol and distilled water between each individual to prevent any contamination. Following removal of pallial fluid, gills of the same individual were also sampled to determine Perkinsus sp. density (see Sect. 2.3.2). The remaining tissue was preserved and subsequently analysed to quantify trematode infections.

\subsection{Detection and quantification of parasites}

The parasite abundance is defined as the number of parasite individuals per host and the prevalence as the percentage of infected hosts within a population (Margolis et al. 1982). Parasite species richness is the number of parasites species per host.

\subsubsection{Brown Ring Disease (BRD) diagnosis and Vibrio tapetis detection}

Disease stage was assessed according to the scale established by Paillard and Maes (1994). In this classification, the degree of symptoms ranges from microscopic brown spots on the inner face of the shell in the early stage of disease to a thick, complete, brown ring in the most advanced stage. The shell repair process, which consists of covering the brown deposit with new calcified layers (nacrezation) (Paillard 1992), was also determined.

For V. tapetis detection, DNA was extracted from the extrapallial fluid according to the chelex method (Saulnier et al. 2000). The use of $V$. tapetis specific primers (SSPVtF and SSPVtR) allowed the amplification of a $416 \mathrm{bp}$ fragment from the $16 \mathrm{~S}$ rDNA as described by Paillard et al. (2006). PCR reactions were performed in $50 \mu \mathrm{l}$ of $10 \mathrm{mM}$ Tris- $\mathrm{Cl}, 50 \mathrm{mM}$ $\mathrm{KCl}$ containing $200 \mu \mathrm{M}$ of each primer, $0.2 \mathrm{U}$ of Taq DNA polymerase (Sigma), and 1-5 $\mu$ l of extraction fluid. The thermal profile consisted of 35 cycles of $1 \mathrm{~min}$ at $94{ }^{\circ} \mathrm{C}, 1 \mathrm{~min}$ at $52{ }^{\circ} \mathrm{C}$, and $1 \mathrm{~min}$ at $72{ }^{\circ} \mathrm{C}$ in a GeneAmp ${ }^{R}$ PCR system 9700 (Applied Biosystem). The positive control consisted of $V$. tapetis CECT 4600 DNA while the negative control was deionised water. PCR amplified DNA fragments were visualised under U.V. illumination by agarose gel electrophoresis $(1 \% \mathrm{w} / \mathrm{v})$ and ethidium bromide staining. Ladders (100 bp DNA ladder Promega and smart ladder Eurogentec) were used as a molecular weight marker. Result of this assay provided the prevalence of $V$. tapetis for each station.

\subsubsection{Perkinsus sp.}

Perkinsus sp. density was assessed according to the quantitative method of Ray (1952) as modified by Choi et al. (1989). Gills were incubated in $10 \mathrm{ml}$ of fluid thioglycollate medium (Difco) supplemented with $100 \mu \mathrm{l}$ of antibiotics (streptomycin and penicillin $\mathrm{G})$. The incubation lasted at least 5 days at room temperature and in darkness. To lyse gills after incubation, the fluid thioglycollate medium was discarded following centrifugation and the remaining tissue digested twice with $2 \mathrm{~N}$ $\mathrm{NaOH}$ at $60{ }^{\circ} \mathrm{C}$ for 1 hour. The resulting solution was centrifuged and the supernatant discarded. Finally, the pellet was washed two times with a sterile solution of Phosphate Buffered Saline (PBS 1X), resuspended in $1 \mathrm{ml}$ of the same solution, and stained with ten microlitres of Lugol's solution.

For clams, the number of Perkinsus sp. hypnospores was estimated using a Nageotte chamber under the light microscope. For cockles, as parasite burden was low, Perkinsus sp. cells were counted using an inverted microscope on the whole sample after transfer to a 24-well micro-plate. Perkinsus sp. density was expressed as the number of cells per gram wet weight of gill tissue.

\subsubsection{Digeneans}

The remaining bivalve tissue (foot, digestive gland, mantle) was pressed between two large glass slides and examined with transmitted light under a stereomicroscope to count and identify digeneans. Cyst diameters were measured and used as a key to determine Himasthla species: H. interrupta $(80-140 \mu \mathrm{m})$, Curtuteria arguinae $(120-180 \mu \mathrm{m})$, H. continua (185-225 $\mu \mathrm{m}), H$. quissetensis $(160-220 \mu \mathrm{m})$ and H. elongata (220-270 $\mu \mathrm{m})$ (Desclaux 2003). The number of collar spines around the oral sucker was used to identify species with same cyst diameter. Meiogymnophallus species were identified according to Bowers et al. (1996). The other digenean species (Psilostomum brevicolle, Diphterostomum brusinae, Renicola roscovita) were identified according to Lauckner (1971) and Werding (1969). Non digenean species (Turbellaria) were identified according to Lauckner (1983). Digenean abundance was expressed as the number of metacercariae per bivalve.

\subsection{Statistical analysis}

Correspondence analysis was applied to ordinate the stations in a reduced space together with their species composition in order to identify the main species contributing to identified groups. Original data consisted of a "station $\times$ species" matrix. This method is recommended for matrices with many zeros because it does not consider a double absence as a similarity criteria.

Significant differences in shell length amongst sites were assessed by the Kruskal-Wallis test, followed by the MannWhitney $U$ test for examination of pairwise differences. The same test was applied to digenean abundance and Perkinsus sp. density. $V$. tapetis prevalences were compared between stations using a proportion comparison test based on Chi-2 test.

For both bivalves, co-infection between digeneans and Perkinsus sp. was assessed using a Spearman correlation test applied to each site individually and then all sites together. To compare digenean or Perkinsus sp. infections between bivalves with and without $V$. tapetis, a Mann-Whitney U test was also applied to each site individually and then all sites together. Statistical analyses were performed using STATISTICA (6.0). 
Table 1. Comparison of total infections (Trematoda, Protozoa, Bacteria) between clams and cockles on the French Atlantic coast (150 individuals for each bivalve species).

\begin{tabular}{llll}
\hline Parasites & Infection rating & Cockles & Clams \\
\hline Trematoda & Mean abundance & 46 metacercariae/host & 1 metacercariae/host \\
& Mean species richness & 3.5 species/host & 0.4 species/host \\
& Prevalence & $95 \%$ & $39 \%$ \\
\cline { 2 - 4 } Perkinsus sp. & Mean density & 36 cells g $^{-1}$ & $30250 \mathrm{cells} \mathrm{g}^{-1}$ \\
& Prevalence & $33 \%$ & $34 \%$ \\
\cline { 2 - 4 } Vibrio tapetis & Prevalence & $31 \%$ & $13 \%$ \\
& (PCR detection) & $10 \%$ & $31 \%$ \\
& Prevalence & & \\
& (Shell, BRD) & &
\end{tabular}

\section{Results}

For both bivalve species, shell length was relatively homogenous along the transect. However, cockle size in Landéda was significantly higher $(p<0.05)$ than those measured in the four other stations. Mean \pm SE size was $24 \pm 5 \mathrm{~mm}$ in cockles, and mean \pm SE size was $33 \pm 3 \mathrm{~mm}$ in clams.

\subsection{Comparisons of infection between cockles and clams}

When all of the individuals sampled (150 individuals for each bivalve species) were examined together, a clear pattern emerged (Table 1). Adult cockles were almost completely parasitized by a community of digenean trematode metacercariae composed of 10 species (95\% prevalence, 46 metacercariae per host, 3.5 species per host). On the other hand, Perkinsus sp. load was very low (36 cells $\mathrm{g}^{-1}$ ). Conversely, clams displayed a low digenean metacercarial burden (39\% prevalence, 1 metacercariae per host, 0.4 species per host) and a relatively high Perkinsus sp. concentration (30250 cells $\left.\mathrm{g}^{-1}\right)$. V. tapetis $(\sim 30 \%)$ and BRD signs $(\sim 10 \%)$ prevalence were similar in both bivalves.

\subsection{The cockle, Cerastoderma edule}

Digenean prevalence in cockles ranged from 80 to $100 \%$. A total of 10 digenean species was identified and the maximum number of species in one individual was 7 (Ile d'Oléron). Correspondence analysis discriminated stations by their species composition and three groups were separated (Fig. 2): a northern group (Landéda and Morbihan) characterised by Himasthla elongata; an intermediate group (Oléron and Noirmoutier) identified by Psilostomum brevicolle, Meiogymnophallus minutus and Himasthla interrupta; a southern group (Arcachon) was isolated with a newly identified species, Curtuteria arguinae (Desclaux et al. 2006). H. quissetensis, $H$. continua and Renicola roscovita were ubiquitous. Digenean abundance varied strongly from site to site ( 8 to 91 metacercariae/cockle) with no relationship to latitude (Fig. 3a). Perkinsus sp. prevalence ranged from 3 to $67 \%$. The density was very low with a maximum in Oléron (103 cells $\mathrm{g}^{-1}$ ) (Fig. 3b).
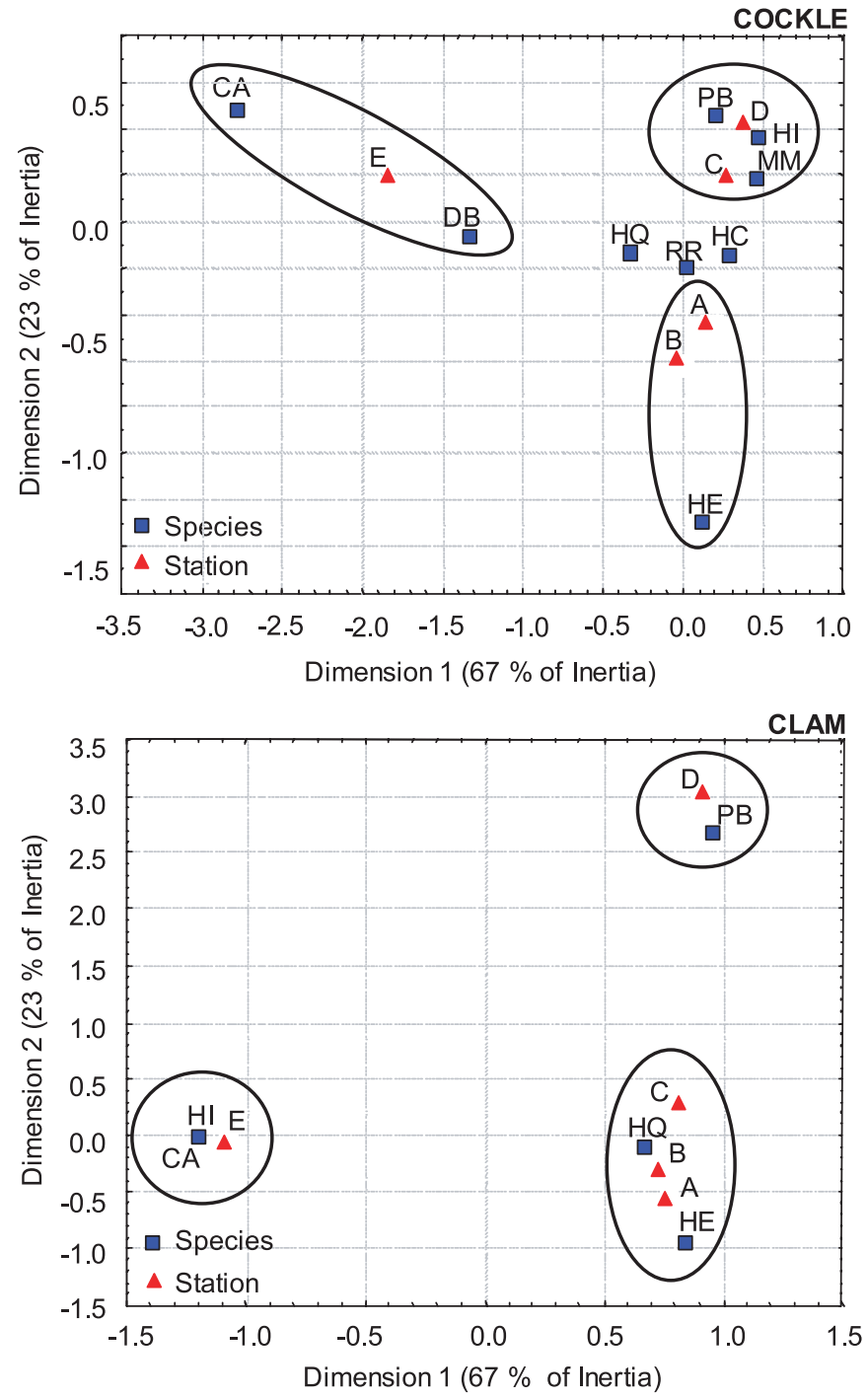

Fig. 2. For cockles and clams, representation of groups of stations and digenean species in the space of the first two dimensions of Correspondence Analysis (HQ: Himasthla quissetensis; HI: H. interrupta; HC: H. continua; HE: H. elongata; CA: Curtuteria arguinae; MM: Meiogymnophallus minutus; PB: Psilostomum brevicolle; DB: Diphterostomum brusinae; RR: Renicola roscovita; A: Landéda; B: Morbihan; C: Noirmoutier; D: Oléron; E: Arcachon). 

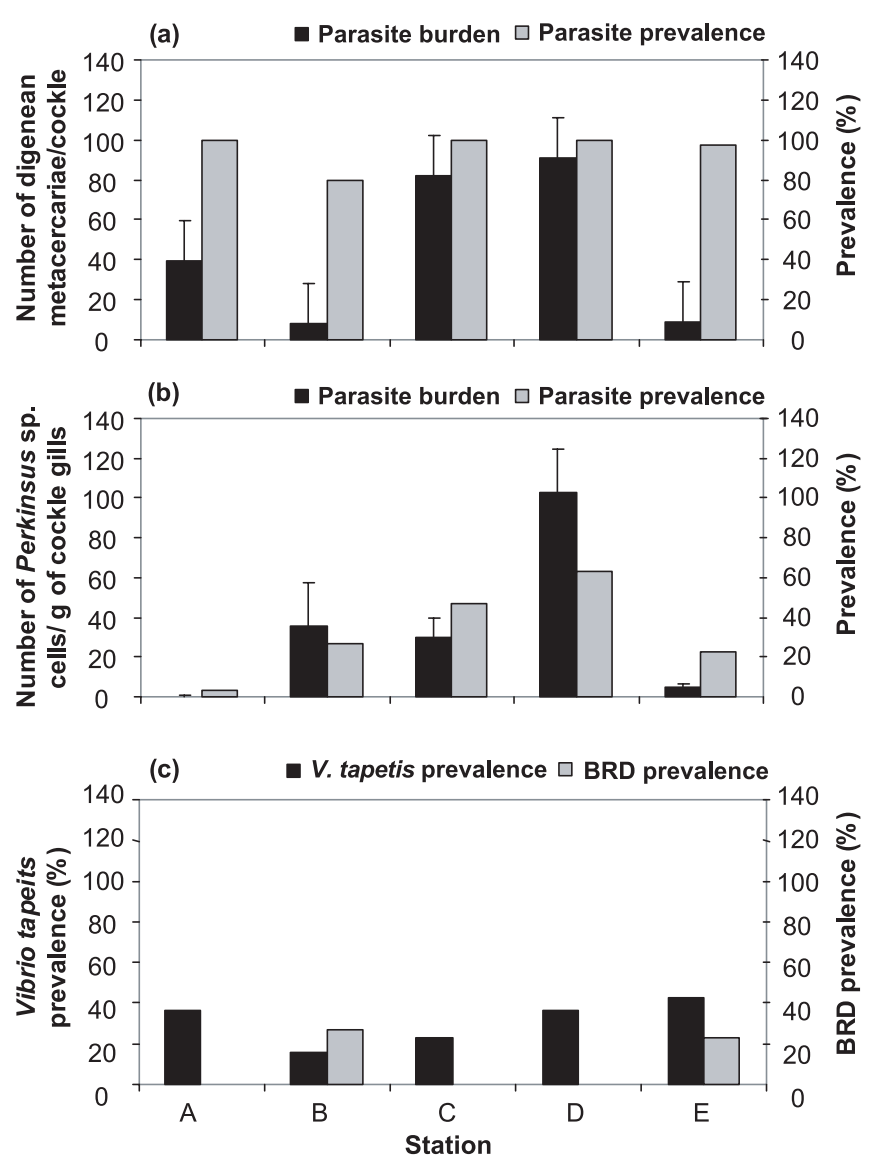

Fig. 3. Digenean burden and prevalence (a), Perkinsus sp. burden and prevalence (b), V. tapetis and Brown Ring Disease (BRD) prevalences (c) in cockles sampled in five stations along the latitudinal gradient.

V. tapetis prevalence decreased from south (Arcachon 43\%) to north (Morbihan 17\%), but increased again at Landéda (37\%) (Fig. 3c). In Morbihan and Arcachon, shells exhibited brown deposits and malformations on their inner shell surfaces similar to the Brown Ring Disease (BRD) symptoms. The disease prevalences were respectively 27 and $23 \%$.

When data for all cockles were pooled, digenean and Perkinsus sp. burdens were correlated $\left(R^{2}=0.27 ; N=150\right.$; $p<0.05)$ However, at the local site scale $(N=30)$, no significant correlation $(p>0.05)$ was found between digenean abundance and Perkinsus sp. density. Similarly, Mann-Whitney U test showed no impact of presence/absence of $V$. tapetis on digenean abundance $(p>0.05)$, at all sites together and separately (Fig. 4).

\subsection{The Manila clam, Ruditapes philippinarum}

Digenean prevalence in Manila clams ranged from 23 to $77 \%$. Five digeneans were identified and the maximum number of species in one clam was 2. Correspondence analysis discriminated the same three groups of stations related to digeneans as for cockles (Fig. 2). Digenean abundance was low (mean $<3$ metacercariae/clam) and similar between stations (Fig. 5a). Mean Perkinsus sp. density increased to the south, from 0 (Landéda) to 90000 cells g ${ }^{-1}$ (Arcachon) with prevalence ranging from 0 to $80 \%$. However, the absence of infection in Oléron constituted an interruption in this gradient (Fig. 5b). V. tapetis prevalence ranged from 23 to $50 \%$ with no relation with latitude (Fig. 5c). Noirmoutier with the lowest prevalence differed significantly from Oléron and Morbihan stations. In Arcachon, shells showed on their inner face brown deposit and malformation like those encountered with the BRD reaching a prevalence of $63 \%$.

When data for all clams were pooled, digenean and Perkinsus sp. burdens were correlated $\left(R^{2}=0.23, N=150\right.$, $p<0.05)$. However, at site scale $(N=30)$, no significant correlation $(p>0.05)$ was found between digenean abundance and Perkinsus sp. density. No significant impact of presence/absence of $V$. tapetis on digenean abundance was observed when considering all sites together $(N=150)$ or separately $(N=30)$ (Fig. 6).

\section{Discussion}

\subsection{Host specificity of pathogens}

As already found by de Montaudouin et al. (2000) in a previous study in Arcachon Bay, digeneans are more prevalent in cockles than in Manila clams. This could be explained by the density of host tissues. Bartoli (1981) noticed that in other species of cockles and clams (Cerastoderma glaucum and Ruditapes decussatus) sampled at the same station, digenean abundance in clams was lower than in cockles. Cockle tissues are softer and may facilitate a high recruitment of metacercariae. Moreover, the fact that cockles were the bivalves most infected by digeneans may also result from a parasite strategy to optimize the likelihood of trophic transmission to complete their life cycle. Cockles are easily available to predators (final hosts of parasites) because they live in a wide tidal range and only a few millimetres under the sediment surface; they may even emerge at the surface when abundance is high, because of sediment erosion, or when they are stressed, such as by oxygen deficiency or infection (Desclaux et al. 2002). Clams present several disadvantages for digenean parasites compared to cockles, such as a deeper position in the sediment and autumn recruitment, when the temperature becomes too low for the emission of cercariae (Wegeberg 1998). Furthermore, Manila clams have been recently introduced to European waters, and are probably free of their natural enemies (Flasch and Leborgne 1992). Indeed, Bachelet et al. (2004) showed that Cyclope neritea, accidentally introduced with oyster transfers to the Bay of Biscay, was not infected by natural parasites, which may have contributed to the successful competition of this nassariid gastropod against the native Nassarius reticulatus. Calvo-Ugarteburu and McQuaid (1998a and 1998b) showed the same phenomenon in South Africa between an introduced mussel Mytilus galloprovincialis and a native mussel Perna perna.

Perkinsus sp. prevalence and density in Manila clams were higher than those measured in cockles. Acquisition of Perkinsus sp. infective stages can be increased for larger bivalves with high filtration capacities. Numerous studies on $P$. marinus and its host, the oyster Crassostrea virginica, showed 

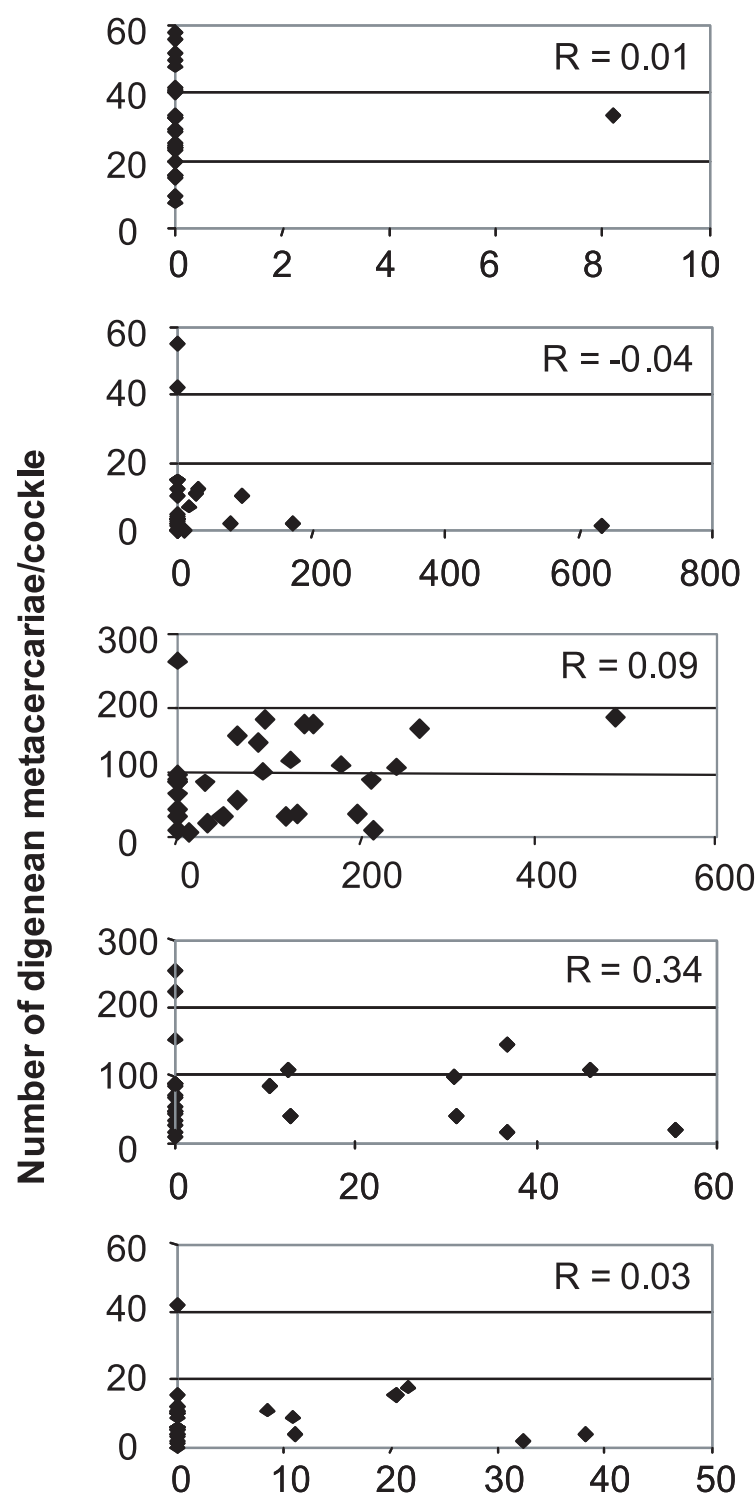

Number of Perkinsus sp. cells/g of gills

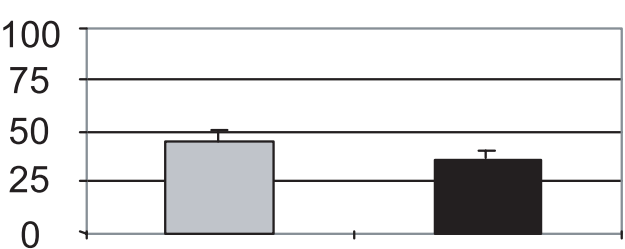

A

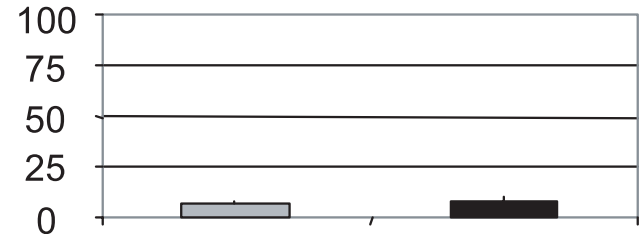

B

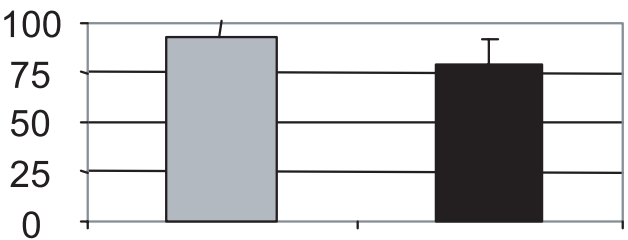

C

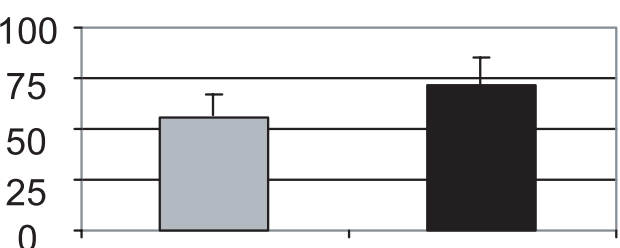

D

$\mathbf{E}$

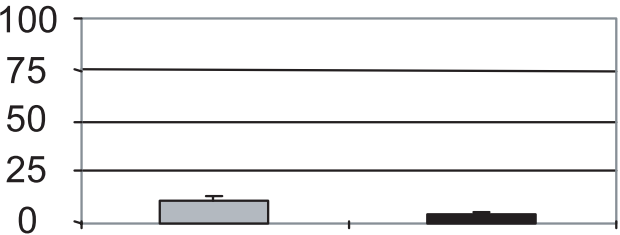

With $V$. tapetis Without $V$. tapetis

Fig. 4. Digenean abundance in relation to Perkinsus sp. density (correlations) and to presence/absence of V. tapetis (Mann-Whitney U test) (grey bars correspond to cockles with V. tapetis and black bars to cockles without the bacterium) for the five sampled stations.

that parasite prevalence was higher in adults than in juveniles and could be explained by higher filtration rates and also by longer exposure to infective particles (Villalba et al. 2004). In the present study, although clam shell length was $33 \mathrm{~mm}$ on average compare to $24 \mathrm{~mm}$ for cockles, animal size alone is unlikely to explain that clams had 840 times more Perkinsus sp. than cockles. There is obviously a species-dependent infection for this protozoan parasite.

Prevalence of Vibrio tapetis was the same for both bivalve species but no quantitative detection was performed. V. tapetis was first isolated in cockles and clams in 1990 in the Bay of Quiberon (Morbihan, France). However, these two isolates were able to induce BRD signs only in Manila clams (Maes and Paillard 1992; Paillard et al. 2006).

\subsection{Interactions of micro- and macroparasites and variability of digenean infection}

At the population scale, Perkinsus sp. and digeneans appeared to have similar distribution patterns for both host species. This may be due to the same parasitic response to environmental conditions. For example, temperature is a major abiotic factor to be taken into account in ecology and population dynamics of these two parasites. Indeed, in vitro study has shown that cultures of $P$. olseni proliferate rapidly at temperatures between 24 and $28{ }^{\circ} \mathrm{C}$ (Auzoux-Bordenave et al. 1995). Moreover, five years of monthly sampling of a Ruditapes decussatus clam bed affected by $P$. olseni revealed an annual pattern of perkinsosis dynamics influenced by temperature (Casas 2002; Villalba et al. 2005). Prevalence 

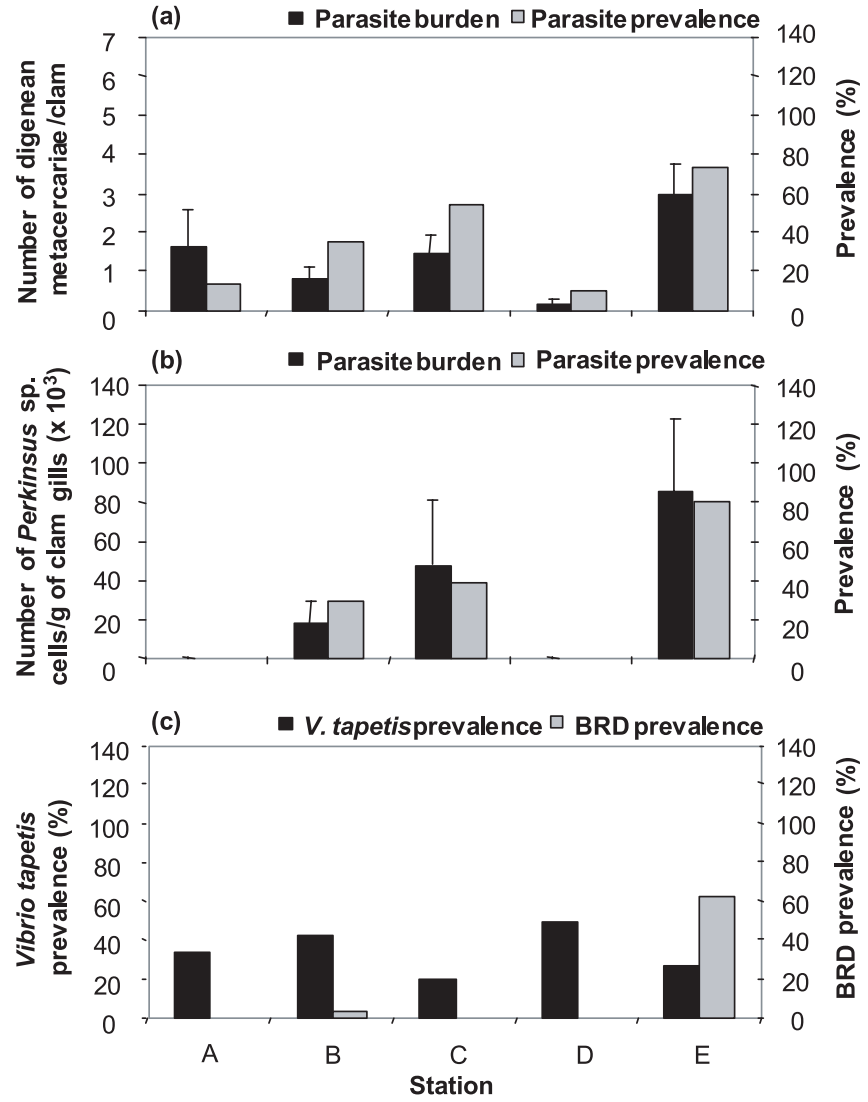

Fig. 5. Digenean burden and prevalence (a), Perkinsus sp. burden and prevalence (b), V. tapetis and Brown Ring Disease (BRD) prevalences (c) in clams sampled in five stations along the latitudinal gradient.

and intensity peaked in spring coupled with increasing temperature (above $15{ }^{\circ} \mathrm{C}$ ) and stayed high through the summer. Infection regression occurred in late autumn and winter coinciding with lower temperature (annual minimum $9-10{ }^{\circ} \mathrm{C}$ ). In the present study, a gradient of increasing Perkinsus sp. abundance along the latitudinal transect confirms this hypothesis. Digeneans also have population dynamics influenced by temperature. Indeed, release of trematode from the first intermediate host and successful transmission to the second intermediate host are highly temperature-dependent (Mouritsen and Jensen 1997; Mouritsen 2002). Accordingly, a study on Maritrema novaezelandensis reported that cercariae emergence from the gastropod Zeacumantus subcarinatus increases threefold when temperature rises from $19{ }^{\circ} \mathrm{C}$ to $25^{\circ} \mathrm{C}$ (Fredensborg and Poulin 2005). Salinity is also an important abiotic factor. It was shown that when oysters infected by $P$. marinus were transferred to a low salinity site, disease progression and mortality were delayed, suggesting a physiological effect of salinity on the parasite (Ray 1954; Andrew and Hewatt 1957). In vitro salinity effects for $P$. marinus parallel the field experiments (Dungan and Hamilton 1995). For P. olseni, the optimal range of salinity is 25-35 psu (Auzoux-Bordenave et al. 1995). As in the present survey, all salinities were within this range, this factor is unlikely to affect Perkinsus sp. distribution between the studied sites. Cercarial emission in the digenean life cycle increases with salinity but no effect has been detected on cercaria life span (Mouritsen 2002). For these two major environmental factors, protozoans and digeneans therefore are favoured by high temperature and high salinity. Furthermore, the two parasites have free-living stages (cercariae for digeneans and zoospores for Perkinsus sp.) and penetrate into host through their inhalant siphons to form metacercariae for digeneans and trophozoites for Perkinsus sp. in host tissues.

At the individual scale, however, when the two hosts were compared at each station, digenean metacercariae abundance was not related to Perkinsus sp. density. This finding is at odds with the common hypothesis that the same ecological niche and the same pool of resources favors interactions. Indeed, just like free-living organisms, parasites occupy suitable habitats (hosts) that are limited with regard to the amount of space and resources available. Competition between parasites is a wellknown phenomenon from studies on adult helminths in their vertebrate hosts (Shostak and Scott 1993) and also from larval trematodes in their snail first intermediate host (Touassem and Theron 1989; Sousa 1993; Kuris and Lafferty 1994). However, P. olseni is most prevalent in the gills (Casas 2002) while digeneans are mainly located in other tissues (Lauckner 1984) and therefore they can be considered as living in distinct tissue niches and resource pool.

Moreover, after the development of metacercariae is completed (just a few hours to a few days after trematode larval penetration), there is no absorption of nutrients across the cyst wall and any physical effect of the parasite on the host is due solely to the presence of the cyst (Fredensborg et al. 2004). This could explain the low rate of observed competition between digenean cysts and Perkinsus sp. trophozoites at the individual scale.

For the two host species, at the population and individual scales, digenean abundance was not influenced significantly by Vibrio tapetis. Nevertheless, the levels of infection of digeneans in both bivalve species were relatively low compared to the several hundreds of metacercariae that can be found in tissues (Thieltges et al. 2006). Consequently, the strength of digenean load as a co-factor of infection remains low.

\subsection{Correspondence BRD diagnosis / Vibrio tapetis detection}

To date, four techniques are available for diagnosis of Brown Ring Disease and V. tapetis detection: 2 PCR assays with different set of primers: PCR assay of Rodríguez et al. (2003, 2006), PCR assay of Paillard et al. (2006), a microbiological method and the shell valve analysis. The PCR assay used in this article is that of Paillard et al. (2006) based on an oligonucleotidic probe and two species-specific PCR primers, deduced from the $16 \mathrm{~S}$ rDNA sequence of $V$. tapetis.

The recent article of Drummond et al. (2006) compared these four techniques and showed that in experimental conditions, none of the four techniques was sufficient on its own for effective BRD diagnosis. Nevertheless, the combination of shell valve analysis with the assay of Paillard et al. (2006) proved to be the most sensitive and rapid test.

A study of clams diagnosed with $40 \%$ prevalence of BRD signs during winter mortalities in the Gulf of Morbihan in 

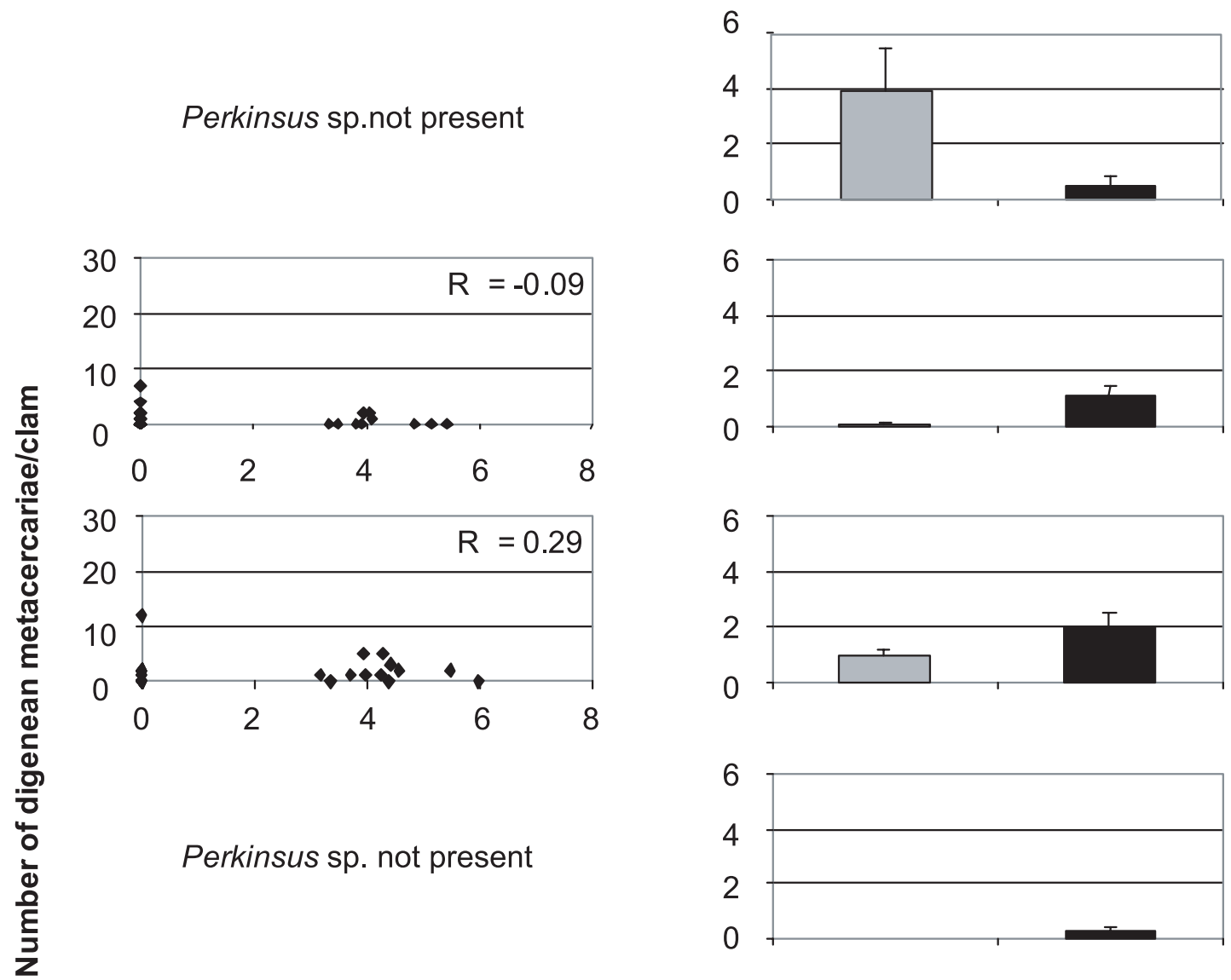

B

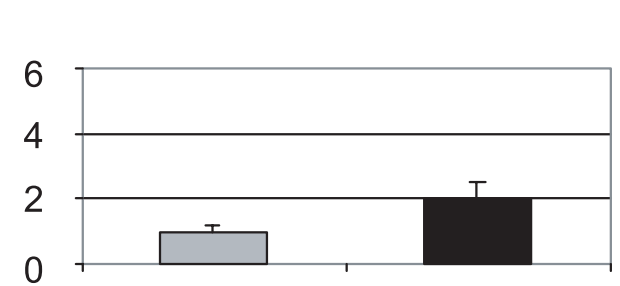

C

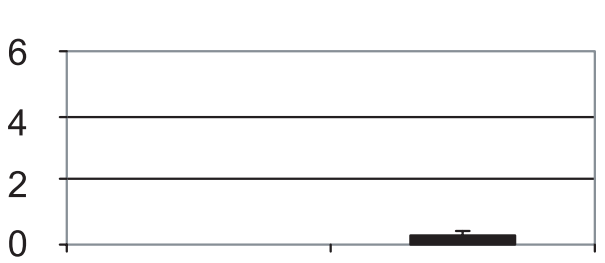

D

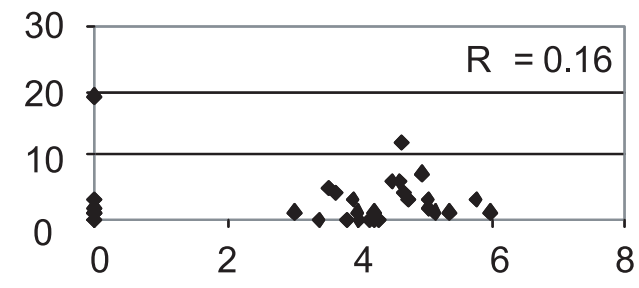

Log(number of Perkinsus sp. cells/g of gills +1 )

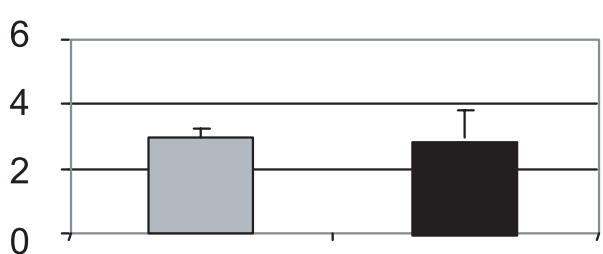

E

With $V$. tapetis Without $V$. tapetis

Fig. 6. Digenean abundance in relation to Perkinsus sp. density (correlations) and to presence/absence of V. tapetis (Mann-Whitney U test). Grey bars correspond to clams with $V$. tapetis and black bars to clams without the bacterium - for the five sampled stations. Perkinsus sp. density is expressed as $\log (x+1)$ where $x$ is the number of cells per gram wet weight of gill tissue.

2002 showed that almost $77 \%$ of symptomatic clams were positively diagnosed for $V$. tapetis by the Paillard PCR assay (Paillard, unpublished data). Similar results were found in cultivated clams from Landéda where $60 \%$ of symptomatic clams were positive for $V$. tapetis using the same assay (Paillard, unpublished data). Conversely, in the present study applied to natural clam stocks, a high percentage of Manila clams with $V$. tapetis were without BRD symptoms. Moreover, BRD is not known to currently occur in Ireland, although its etiological agent has recently been detected in asymptomatic Manila clams from a number of natural sites around the Irish Coast (Drummond et al. 2007). The same phenomenon was recorded at all five stations sampled in this study. For example, a high $V$. tapetis prevalence was registered in Oléron (50\%) without BRD symptoms.
Cockles can be considered to be "carrier species" that present no BRD symptoms in natural conditions and that develop no signs of conchiolin deposit after challenge tests with V. tapetis (Maes and Paillard 1992). On the other hand, BRD symptoms in cockles were observed in two stations in this study (Arcachon and Morbihan). Trematodes particularly Gymnophhalidae are also known to disturb the pallial edge by shell boring, by irritating the epithelium or by living within mantle tissue and result thus in BRD like symptoms (Paillard et al. 1994; Paillard et al. 1996). However, Meiogymnophallus minutus is the only Gymnophallidae in this study with a low abundance and which live aggregated in a pouch below the shell hinge.

This study showed how diversified and complex a parasite (micro and macroparasites) community can be. V. tapetis, 
Perkinsus sp. and digenean trematodes were present in both bivalves but displayed a specific infection pattern in relation to host. Moreover, there appeared to be little interactions taking place between the parasites, possibly because parasite intensities were relatively low in the present survey.

Acknowledgements. The authors are grateful to P. Lebleu for his highly valuable help during the sampling period and E. Ferré for her help during sample analysis of Perkinsus sp. Sincere thanks are due to K. Limburg and Susan Ford for English corrections and anonymous reviewer for comments on the manuscript. The study was carried out with financial support from the "Programme National Environnement Côtier" (PNEC) and was included in the "Transversal Action: Impact of PArasites on Marine ORganisms and populations and modulation by the environmental factors" (TAIPAMOR).

\section{References}

Andrew J.D., Hewatt W.G., 1957, Oyster mortality studies in Virginia: II. The fungus disease caused by Dermocystidium marinum in oysters of Chesapeake Bay. Ecol. Monogr. 27, 1-25.

Auzoux-Bordenave S., Vigario A.M., Ruano F., Domart-Coulon I., Doumenc D., 1995, In vitro sporulation of the clam pathogen Perkinsus atlanticus (Apicomplexa, Perkinsea) under various environmental conditions. J. Shellfish Res. 14, 469-475.

Bachelet G., Simon-Bouhet B., Desclaux C., Garcia-Meunier P., Mairesse G., de Montaudouin X., Raigne H., Randriambao K., Sauriau P.G., Viard F., 2004, Invasion of the eastern Bay of Biscay by the nassariid gastropod Cyclope neritea: origin and effects on resident fauna. Mar. Ecol. Prog. Ser. 276, 147-159.

Bartoli P., 1981, Démographie et phénomène de compétition intraspécifique des Gymnophallidae Morozov chez les deuxièmes hôtes intermédiaires (Trematoda, Digenea). Ann. Parasitol. 56, 33-44.

Bowers E.A., Bartoli P., Russel-Pinto F., James B.L., 1996, The metacercariae of sibling species of Meiogymnophallus, including M. rebecqui comb. nov. (Digenea: Gymnophallidae), and their effects on closely related Cerastoderma host species (Mollusca: Bivalvia). Parasitol. Res. 82, 505-510.

Calvo-Ugarteburu G., McQuaid C.D., 1998a, Parasitism and introduced species: epidemiology of trematodes in the intertidal mussels Perna perna and Mytilus galloprovincialis. J. Exp. Mar. Biol. Ecol. 220, 47-65.

Calvo-Ugarteburu G., McQuaid C.D., 1998b, Parasitism and invasive species: effects of digenetic trematodes on mussels. Mar. Ecol. Prog. Ser. 169, 149-163.

Casas S.M., 2002. Estudio de la perkinsosis en la almeja fina Tapes decussatus (Linnaeus, 1758), de Galicia. PhD Thesis, University of Santiago de Compostela, Spain.

Choi K.S., Wilson E.A., Lewis D.H., Powell E.N., Ray S.M., 1989, The energetic cost of Perkinsus marinus parasitism in oysters: quantification of the thioglycollate method. J. Shellfish Res. 8, 125-131.

de Montaudouin X., Kisielewski I., Bachelet G., Desclaux C., 2000, A census of macroparasites in an intertidal bivalve community, Arcachon Bay, France. Oceanol. Acta 23, 453-468.

Desclaux C., 2003. Interactions hôtes-parasites: diversité, mécanismes d'infestation et impact des trématodes digènes sur les coques Cerastoderma edule (mollusque bivalve) en milieu lagunaire macrotidal. Thèse de Doctorat, Université Bordeaux I.

Desclaux C., de Montaudouin X., Bachelet G., 2002, Cockle emergence at the sediment surface "favourization" mechanism by digenean parasites? Dis. Aquat. Org. 52, 137-149.
Desclaux C., Russell-Pinto F., de Montaudouin X., Bachelet G., 2006, First record and description of metacercariae of Curtuteria arguinae n. sp. (Digenea: Echinostomatidae), parasite of cockles Cerastorderma edule (Mollusca: Bivalvia) in Arcachon Bay, France. J. Parasitol. 92, 578-587.

Drummond L.C., Balboa S., Beaz R., Mulcahy M.F., Barja J.L., Culloty S.C., Romalde J.L., 2007, The susceptibility of Irishgrown and Galician-grown Manila clams, Ruditapes philippinarum, to Vibrio tapetis and Brown Ring Disease. J. Invertebr. Pathol.

Drummond L.C., O’Reilly P., Mulcahy M.F., Culloty S.C., 2006, Comparison of techniques for diagnosis of Brown Ring Disease and detection of Vibrio tapetis in the Manila clam, Venerupis (Ruditapes) philippinarum. J. Shellfish Res. 25, 1043-1049.

Dungan C.F., Hamilton R.M., 1995, Use of a tetrazolium-based cell proliferation assay to measure effects of in vitro conditions on Perkinsus marinus (Apicomplexa) proliferation. J. Eukaryot. Microbiol. 42, 379-388.

Flasch J.P., Leborgne Y., 1992, Introduction in Europe, from 1972 to 1980, of the manila clam (Tapes philippinarum) and effects on aquaculture production and natural settlement. ICES J. Mar. Sci. 194, 92-96.

Fredensborg B.L., Mouritsen K.N., Poulin R., 2004, Intensitydependent mortality of Paracalliope novizealandiae (Amphipoda: Crustacea) infected by a trematode: experimental infections and field observations. J. Exp. Mar. Biol. Ecol. 311, 253-265.

Fredensborg B.L., Poulin R., 2005, Larval helminths in intermediate hosts: Does competition early in life determine the fitness of adult parasites? Int. J. Parasitol. 35, 1061-1070.

Jensen K.T., Castro N.F., Bachelet G., 1999, Infectivity of Himasthla spp. (Trematoda) in cockle (Cerastoderma edule) spat. J. Mar. Biol. Assoc. UK 79, 265-271.

Kuris A.M., Lafferty K.D., 1994, Community structure: Larval trematodes in snail hosts. Annu. Rev. Ecol. Syst. 25, 189-217.

Lauckner G., 1971, Zur trematodenfauna der herzmuscheln Cardium edule und Cardium lamarcki. Helgol. Meeresunters 22, 377-400.

Lauckner G., 1983, Disease of Mollusca: Bivalvia. In: Kinne O. (Ed) Disease of Marine Animals, Biologische Anstalt Helgoland, pp. 477-961.

Lauckner G., 1984, Impact of trematode parasitism on the fauna of the North Sea tidal flat. Helgol. Meeresunters 37, 185-199.

Maes P., Paillard C., 1992, Effect du Vibrio P1, pathogène de Ruditapes philippinarum, sur d'autres espèces de bivalves. Les Mollusques marins, Biologie et Aquacultures. Ifremer, Actes de Colloques 14, 141-148.

Margolis L., Esch G.W., Holmes J.C., Kuris A.M., Schad G.A., 1982, The use of ecological terms in parasitology (report of an ad hoc committee of the American Society of Parasitologists). J. Parasitol. 68, 131-133.

Mouritsen K.N., 2002, The Hydrobia ulvae-Maritrema subdolum association: influence of temperature, salinity, light, waterpressure and secondary host exudates on cercarial emergence and longevity. J. Helminthol. 76, 341-347.

Mouritsen K.N., Jensen K.T., 1997, Parasite transmission between soft-bottom invertebrates: Temperature mediated infection rates and mortality in Corophium volutator. Mar. Ecol. Prog. Ser. 151, 123-134.

Ngo T.T.T., Choi K.S., 2004, Seasonal changes of Perkinsus and Cercaria infections in the Manila clam Ruditapes philippinarum from Jeju, Korea. Aquaculture 239, 57-68.

Paillard C., 1992. Etiologie et caractérisation de la maladie de l'anneau brun chez la palourde d'élevage, Ruditapes philippinarum. Thèse de Doctorat, Université de Brest. 
Paillard C., 2004, A short-review of brown ring disease, a vibriosis affecting clams, Ruditapes philippinarum and Ruditapes decussatus. Aquat. Living Resour. 17, 467-475.

Paillard C., Ashton-Alcox K.A., Ford S.E., 1996, Changes in bacterial densities and hemocyte parameters in oysters affected by Juvenile Oyster Disease. Aquat. Living Resour. 9, 145-158.

Paillard C., Gausson S., Nicolas J.L., Le Pennec J.P., Haras D., 2006, Molecular identification of Vibrio tapetis, the causative agent of the brown ring disease of Ruditapes philippinarum. Aquaculture 253, 25-38.

Paillard C., Maes P., 1994, Brown Ring Disease in the Manila clam Ruditapes Philippinarum - Establishment of a classification system. Dis. Aquat. Org. 19, 137-146.

Paillard C., Maes P., 1995a, The Brown Ring Disease in the Manila clam, Ruditapes Philippinarum .1. Ultrastructural alterations of the periostracal lamina. J. Invertebr. Pathol. 65, 91-100.

Paillard C., Maes P., 1995b, The brown ring disease in the Manila clam, Ruditapes philippinarum: II. Microscopic study of the brown ring syndrome. J. Invertebr. Pathol. 65, 91-100.

Paillard C., Maes P., Oubella R., 1994, Brown ring disease in clams. Annu. Rev. Fish Dis. 4, 219-240.

Ray S.M., 1952, A culture technique for the diagnosis of infections with Dermocystidium marinus Mackin, Owen and Collier in Oysters. Science 116, 360-361.

Ray S.M., 1954, Biological studies of Dermocystidium Marinus, a fungus parasite of oysters. Rice Institute Pamphlet 14, 114.

Rodríguez J.M., López-Romalde S., Beaz R., Carmen Alonso M., Castro D., Romalde J.L., 2006, Molecular fingerprinting of Vibrio tapetis strains using three PCR-based methods: ERICPCR, REP-PCR and RAPD. Dis. Aquat. Org. 69, 175-183.

Rodríguez J.M., Toranzo A.E., Romalde J.L., 2003, Development and optimization of a new PCR-based protocol for rapid diagnosis of Vibrio tapetis, the causative agent of brown ring disease in clams. In: Abstracts of XIth International Conference of the European Association of Fish Pathologists (EAFP).
Saulnier D., Avarre J.C., Le Moullac G., Ansquer D., Levy P., Vonau V., 2000, Rapid and sensitive PCR detection of Vibrio penaeicida, the putative etiological agent of Syndrome 93 in New Caledonia. Dis. Aquat. Org. 40, 109-115.

Shostak A.W., Scott M.E., 1993, Detection of density-dependent growth and fecundity of helminths in natural infections. Parasitology 106, 527-539.

Sousa W.P., 1993, Interspecific antagonism and species coexistence in a diverse guild of larval trematode parasites. Ecol. Monogr. 63, 103-128.

Thieltges D.W., Krakau M., Andresen H., Fottner S., Reise K., 2006, Macroparasite community in molluscs of a tidal basin in the Wadden Sea. Helgol. Mar. Res. 60, 307-316.

Touassem R., Theron A., 1989, Schistosoma rodhaini: Dynamics and cercarial production for mono- and pluri-miracidial infection of Biomphalaria glabrata. J. Helminthol. 63, 79-83.

Villalba A., Casas S.M., Lopez C., Carballal M.J., 2005, Study of perkinsosis in the carpet shell clam Tapes decussatus in Galicia (NW Spain). II. Temporal pattern of disease dynamics and association with clam mortality. Dis. Aquat. Org. 65, 257-267.

Villalba A., Reece K.S., Ordás M.C., Casas S.M., Figueras A., 2004, Perkinsosis in molluscs: a review. Aquat. Living Resour. 17, 411432.

Wegeberg A.M., 1998. Digene trematoders (Echinostomatidae) infectionsokologi og effekt pa Cerastoderma edule. $\mathrm{PhD}$ Thesis, University of Aarhus.

Wegeberg A.M., de Montaudouin X., Jensen K.T., 1999, Effect of intermediate host size (Cerastoderma edule) on infectivity of cercariae of three Himasthla species (Echinostomatidae, Trematoda). J. Exp. Mar. Biol. Ecol. 238, 259-269.

Werding B., 1969, Morphologie, entwicklung und ökologie digener trematoden-larven der standschnecke Littorina littorea. Mar. Biol. 3, 306-333. 